\title{
Kentsel Yayılma Sonucu Tarım Alanlarında Oluşan Değer Değişimi: Yalova (Kadıköy) Örneği
}

\author{
Canan Koç ${ }^{1}$ Ahmet Koç ${ }^{2}$
}

\author{
${ }^{1}$ Dicle Üniversitesi, Mimarlık Fakültesi Şehircilik Anabilim Dalı, Diyarbakır, \\ ${ }^{2}$ Iğdır Üniversitesi, Ziraat Fakültesi Peyzaj Mimarlığı Bölümü, Iğdır \\ *Sorumlu yazar: canan.koca@dicle.edu.tr
}

Geliş Tarihi: 11.04.2019

Kabul Tarihi: 26.11.2019

\section{$\ddot{O} z$}

Kentleşme ve nüfus artışı ile birlikte genelde kent yakınında bulunan tarım alanlarına doğru yayılma olmakta ve bu durum tarım yapılan toprakların imara açılmasıyla sonuçlanmaktadır. Arsalarda değer artışıyla birlikte yapılaşma giderek artmaktadır. Değer artışları ekonomik canlılık sağlamakla birlikte, tarım alanlarındaki yapılaşma baskısı gibi nedenlere bağlı olarak ekolojik yapının bozulmasına yol açabilmektedir. Arsa değerini belirleyen etmenler arasında imar planları önemli bir yere sahiptir. Yapılaşmayı yönlendiren planların tarım alanlarını dikkate alarak yapılması gereklidir. Bu bağlamda, çalışmada, Yalova kent merkezinin etki alanında olan Kadıköy Belediyesi sınırları içinde yer alan okullar bölgesi incelenmiştir. Tarım alanlarında dönüşümün yaşandığ

Anahtar Kelimeler: Tarım alanı, arsa değeri, kentleşme, Yalova

\section{Changes In Value Of Agricultural Areas By Urban Expansıon: Case Of Yalova (Kadıköy) \\ Abstract}

By urbanization and population growth, it is generally spread towards agricultural areas near the city. This situation results in structuring on agricultural land. With the increase in the value of the land, the building continue to increase. While the value increases in the land provide economic livelihood, they can lead to deterioration of ecological structure due to reasons such as the pressure of construction in agricultural areas. Among the factors that determine the value of the land, development plans have an important place. The plans that direct the construction should be made by taking into account the agricultural areas. In this context in the study, the region of the schools within the boundaries of Kadikoy Municipality which is impact area of Yalova city center, has been investigated. The changes in the value of the land in this region where the transformation in agricultural areas are experienced are examined.

Keywords: Agricultural areas, land value, urbanization, Yalova

\section{Giriş}

Kentlerdeki nüfus artışına bağlı olarak ortaya çıkan plansız ve kontrolsüz yapılaşmalar giderek kent çeperindeki tarım alanlarına doğru yayılmaktadır. Artan nüfusun mekansal gereksinimleri kent içi boşluklardan başlamak üzere, kentin yapılı yakın çevresi ve sonrasında doğal kaynakları içinde barındıran kırsal alanlarda üretilmeye başlanmaktadır (Yenigül, 2016). Bu durum kentin, kırsal topluluklara ekonomik ve toplumsal yönlerden egemen olması ile sonuçlanmakta ve doğal kaynaklar hızlı bir şekilde tüketilmektedir (Sezgin ve Varol, 2012). Kentlerin gelişmesi için yapılan her türlü fiziksel müdahale ve kentsel işlevler için getirilen mekânsal kullanım kararları toprağın kullanış biçimini belirlemektedir (Sezgin ve Varol, 2012).

Avcılık ve toplayıcılıkla geçinen ilkel hayattan tarım toplumuna geçişle birlikte, sulama imkanı olan verimli alanlar işlenmeye başlamış ve kırsal yerleşim alanları ortaya çıkmıştır. Kentler, nüfus artışı ve göç nedeniyle büyürken, tarım topraklarını kent toprağına dönüştürmekte, tarımsal topraklar, imar hakları ve alt yapı koşulları yerine getirilerek, kent toprağı olarak yeniden üretilmektedir (Nas, 2016). Böylece de kentlerde bir yandan kamunun eylem ve işlemleri sonucu rant oluşurken, diğer yandan kentsel toprakların konumlarındaki oransal değişme nedeniyle tekelci rantlar oluşmaktadır(Ökmen ve Yurtsever, 2010). Türkiye'de tarımın gelişmesi Cumhuriyetle birlikte başlamış, tarımın geliştirilmesine yönelik yatırımlar yapılmıştır (Dernek, 2006). 1950'lerde ise 
yaygınlaşan sanayileşme etkisiyle kırın iticiliği ve kentin çekiciliği karşısında kırdan kente göç hızlanmıştır. Günümüzde kentleşme olgusu tarım toprakları üzerindeki baskıyı giderek artırmaktadır. Kentsel alanda oluşan rantın tarımsal getiriye göre daha yüksek ve riskin az olması sebebiyle, tarım alanları hızla kentsel kullanımlara ve özellikle konut kullanımına dönüşmekte, kırsal alandaki toprak varlığına arsa stoku gözüyle bakılmaktadır (Sezgin ve Varol, 2012). Yerleşim alanları civarındaki tarım arazilerinin arsaya dönüşmesi ile değerinde meydana gelen ani artış, bu arazilerin tarımsal niteliğinin korunmasını güçleştirmektedir (Akci ve ark., 2016). Tarım arazisinin imara açılıp arsa olarak daha fazla gelir getireceği düşüncesi, bu alanlara tarımsal yatırım yapılmasını engelleyen en önemli nedendir (K1lıç, 2008).

Arazilerin potansiyellerine uygun şekilde değerlendirilmesi doğal kaynaklarının sürdürülebilir kullanımında temel esastır. "Ülkemizde tarım arazilerinin en temel sorunları erozyon ve tarım arazilerinin tarımsal amaçlar dışında kullanılmasıdır" (Özbek ve Öztaş, 2004; Akci ve ark., 2016). "Tarım arazilerinin amaç dışı kullanımının en yaygın görüldüğü alanlar sırasıyla sanayi, konutkentleşme, turizm ve madencilik ile ulaştırma amaçlı kamu yatırımları şeklinde sıralanmaktadır" (Akci ve ark. 2016). Tarım dışı kullanım sonucu tarım toprakları geri dönüşümü olmayacak şekilde yok olma tehlikesi ile karşı karşıya kalmaktadır. Doğal sistemlerdeki en büyük değişiklikler arazi kullanımı ile arazi örtüsü değişimlerdir. Arazi kullanımı ve arazi örtüsü oranının değişmesi ekolojik süreci etkilemektedir (Fan ve ark., 2016). İnsan faaliyetleri sonucu etkilenen ekolojik süreç, ekosistem tahribatlarının itici gücünü oluşturmaktadır (Rees and Wackernagel, 2008). Bu tahribatlar ekosistem hizmetlerinin bozulmasına neden olduğundan dolayı insanların gıda ihtiyaçları etkilenmektedir. Tarım arazisi ihtiyacının çayır ve mera arazilerinden karşılanarak ekolojik denge ve biyolojik dengenin bozulması gibi hususlar, tarım arazilerinin korunması ve etkin kullanımının sağlanmasının gerekliliğini ortaya koymaktadır (Topçu, 2012; Akci ve ark., 2016). Tarım arazileri ile mekânsal kullanımlar arasındaki dengenin sağlanması, bu kaynakların sürdürülebilirliğinde önem taşımaktadır (Akci ve ark., 2016). Denizi, ormanı ve tarım alanları ile doğal güzelliklere sahip yerleşmelerden biri olan Yalova'da artan nüfus karşısında oluşan yapılaşma kırsal alanları etkilemektedir. Yalova'nın fay hattına yakınlığı ve kentte jeolojik açıdan sakıncalı alanların varlığı dikeyde yayılma yerine yatayda yayılmayı zorunlu kılmaktadır. Kent merkezinin doygunluğa ulaşması çeperdeki kırsal alanlara yönelimi artırmaktadır. Bu bağlamda, nüfus artışı ve depremselliğe bağlı olarak kırsal alanlarda yapılaşmanın artması ile arsa değerlerinde ortaya çıkan değişimin irdelenmesi çalışmanın amacını oluşturmaktadır. Çalışmada, Yalova kentinin etkisi altında kalan ve tarım alanlarının bulunduğu Kadıköy beldesi sınırları içindeki bölge seçilerek, arsa değerlerindeki değişimler ortaya konmaktadır. Kentin gelişme yönü içinde konumlanması, Yalova'daki önemli okulların bu bölgede yer alması ve son dönemde üst gelir grubunun yaşam alanı içinde bulunması ve arsa değerlerindeki değişimin net olarak görülmesi sebebiyle bu bölge ele alınmaktadır.

\section{Materyal ve Yöntem}

Çalışma alanı, parsel değerini etkileyen özellikler doğrultusunda değerlendirilmektedir. Parselin şeklinden parselin hissedar sayısına kadar birçok kriter ekonomik değerini etkilemektedir. Bu bağlamda, arsa değeri üzerinde önemli etkileri bulunan aşağıda belirtilen kriterler çerçevesinde çalışma alanının ele alınması çalışmanın yöntemini oluşturmaktadır.

Topoğrafik özellikler,

Toprak kalitesi,

Gürültü,

Parselin şekli (Parsel kırık köşe sayısının fazlalığı, proje ve inşaat giderlerini etkiler) (Yomralığlu, 1992),

Parselin yola olan cephesi,

Manzara, 
Eğitim tesisi, sağlık tesisi, dini tesis, alışveriş merkezi, rekreasyon alanları, park gibi sosyal donatı alanlarına olan mesafe,

Şehir merkezi ve farklı ulaşım türlerine olan mesafe,

İmar durumu ve Taks/Kaks değerleri,

Yaşanılan yerin sosyo-ekonomik özellikleri,

Hukuki durum (Taşınmazın hukuki durumunun ihtilaflı, hatta davalı olması değerini olumsuz etkiler)

Malik (hissedar) sayısı (Hissedar sayısı arttıkça değer düşer) (Anonim, 2019a).

Çalışmada, Yalova ili, merkez ilçesi, Kadıköy belediyesi sınırları içinde kalan "Okullar Bölgesi" olarak adlandırılan Kadı Caddesi ve Ahmet Yesevi Caddesi'ndeki parseller ele alınmıştır (Şekil 1). Kadıköy Belediyesi'nden temin edilen son 20 yıla ait $\mathrm{m}^{2}$ arsa değerlerindeki değişim incelenmiştir.

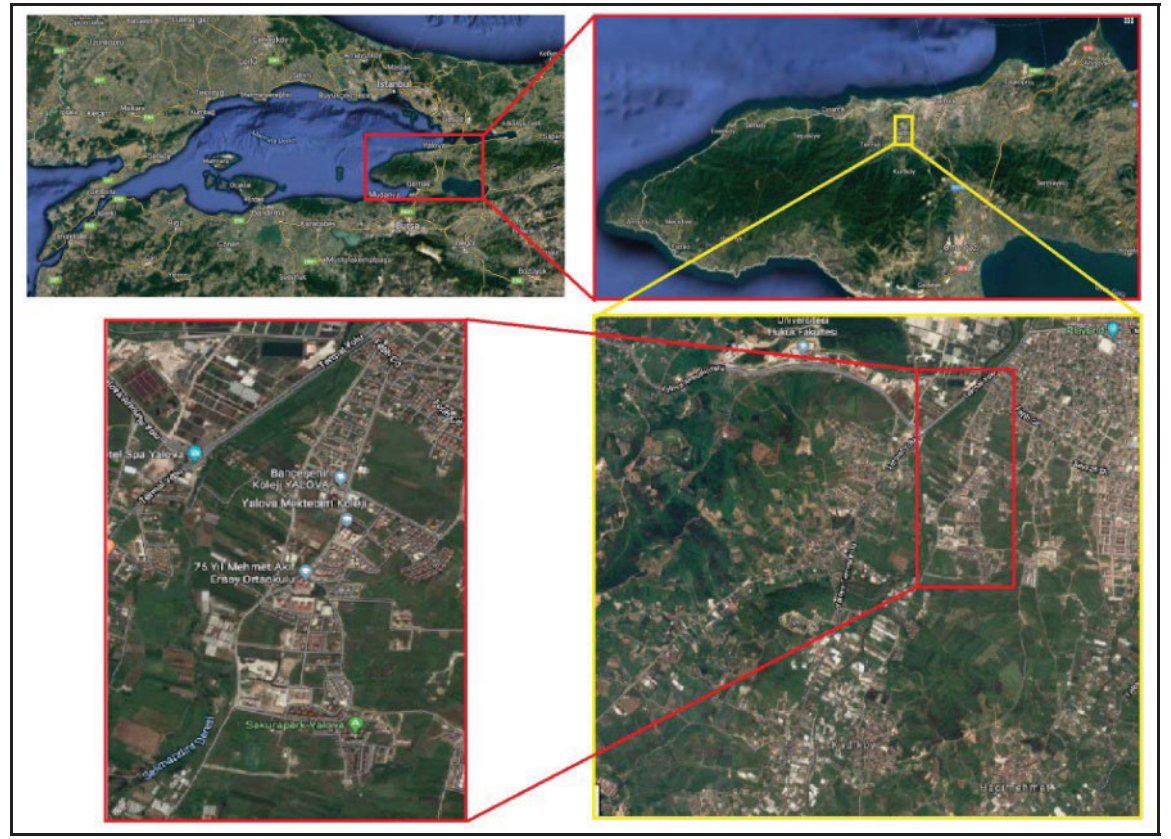

Şekil 1. Çalışma alanı konumu

Çalışma alanı, $40^{\circ} 38^{\prime} \mathrm{K}$ ile $29^{\circ} 14^{\prime} \mathrm{D}$ koordinatları arasında yer almakta ve yaklaşı 130 ha'lık alan kaplamaktadır. Konuyla ilgili literatür taranmış, imar planları ve raporlarından yararlanılmış, yerinde gözlemler yapılmış ve alana ilişkin uydu görüntüleri kullanılmıştır.

\section{Bulgular ve Tartışma}

Çalışma alanın konumlandığ1 Kadıköy, 1870'lerde Batum'dan gelenlerin ve 1921'de mübadele ile daha çok Yunanistan'dan gelen göçmenlerin yerleştiği bir yerleşmedir. 1992 yılında belde belediyesi statüsü kazanmış ve zamanla Yalova merkeze doğru kuzey yönünde gelişme göstermiştir. Belde ekonomisi çoğunlukla tarıma dayalı olup, farklı sektörlerde çalışanlar da bulunmaktadır.

Çalışma alanında yükselti batıdan doğuya doğru artmakta ve yapılaşmayı zorlaştıran eğim bulunmamaktadır. Batıda Selimandıra Deresinin ve taşkın alanlarının bulunması, yapılaşmanın daha çok doğu tarafında yaygınlaşmasına sebep olmaktadır. Aynı zamanda batıya doğru artan eğim manzara üzerinde etkisi oluşturmaktadır. 
Çalışma alanı ve yakın çevresine ait mevcut arazi kullanımı incelendiğinde şehir yapısı, tarım alanları ve yer yer yapılaşmanın bulunduğu karışık tarım alanları görülmektedir (Şekil 2). Yalova'nın güneye doğru olan gelişme yönü içinde konumlanan çalışma alanı, önemli eğitim tesislerinin açılması ve Yalova merkeze yakınlığı gibi sebeplerle çekici hale gelmiş, nüfus ve yapılaşma baskısı altında kalmaya başlamıştır. Özellikle 2010 yılı sonrasında hızla imar faaliyetleri artmıştır. Daha çok dubleks yada tripleks şeklinde, site niteliğinde inşa edilen konutlar gelir düzeyi yüksek kesim tarafından tercih edilmektedir.

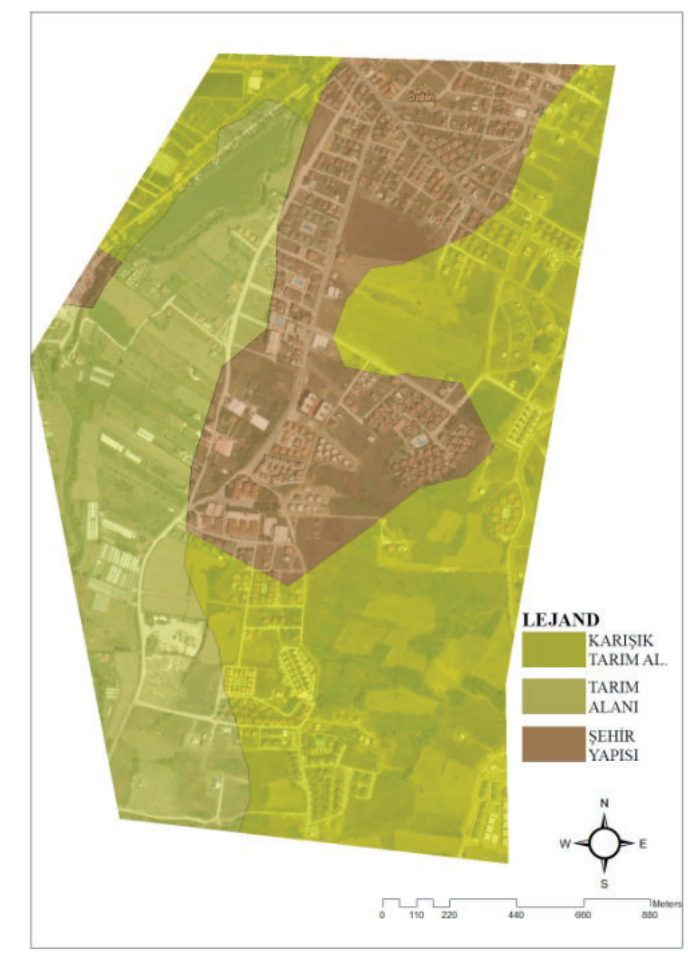

Şekil 2. Mevcut arazi kullanım bilgileri

TUIKK verilerine göre 2010 y1lı nüfusu 5414 kişi olan Kadıköy, 2014 yılında 7060 ve 2018'de 7886 kişilik nüfusa sahip olmuştur. Nüfus verileri beldenin göç aldığını destekler niteliktedir. Artan nüfusa bağlı olarak çalışma alanı sınırları içindeki yapılaşma giderek artmış, 2006 yılında 21,7 ha olan yapılaşmış alan, 2018 yılında \% 110'luk bir artış ile 45,6 Ha olmuştur (Şekil 3). 
ÇOMÜ Zir. Fak. Derg. (COMU J. Agric. Fac.)

2019: 7 (2): 289-298

ISSN: $2147-8384$ / e-ISSN: 2564-6826

doi: $10.33202 /$ comuagri.552760

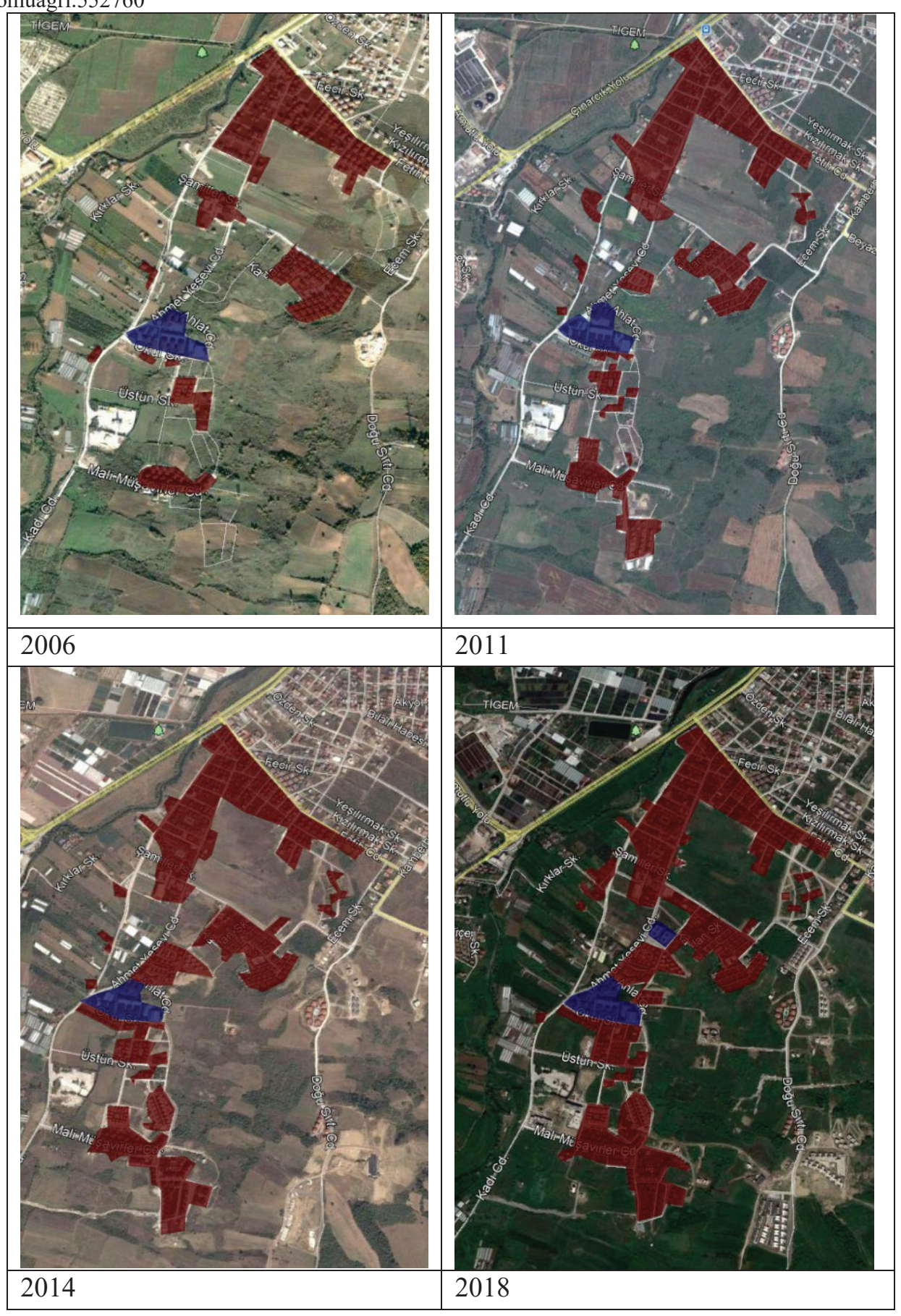

Şekil 3. Çalışma alanının yıllara göre değişimi (2006-2018)

Çalışma alanındaki değişimlerin arsa değerlerine yansımasına bakıldığında üç farklı bölge ${ }^{1}$ ve kırılma noktaları ortaya çıkmaktadır (Şekil 4). Üç bölgede de arsa değerlerindeki artış 2010 yılına kadar stabil iken 2010, 2014 ve 2018 yıllarında ani fiyat artışları yaşanmıştır.

\footnotetext{
${ }^{1}$ Çalışma kapsamında, bu bölgeler A, B, C Bölgeleri şeklinde adlandırılmıştır.
} 
ÇOMÜ Zir. Fak. Derg. (COMU J. Agric. Fac.)

2019: 7 (2): 289-298

ISSN: $2147-8384$ / e-ISSN: 2564-6826

doi: $10.33202 /$ comuagri.552760

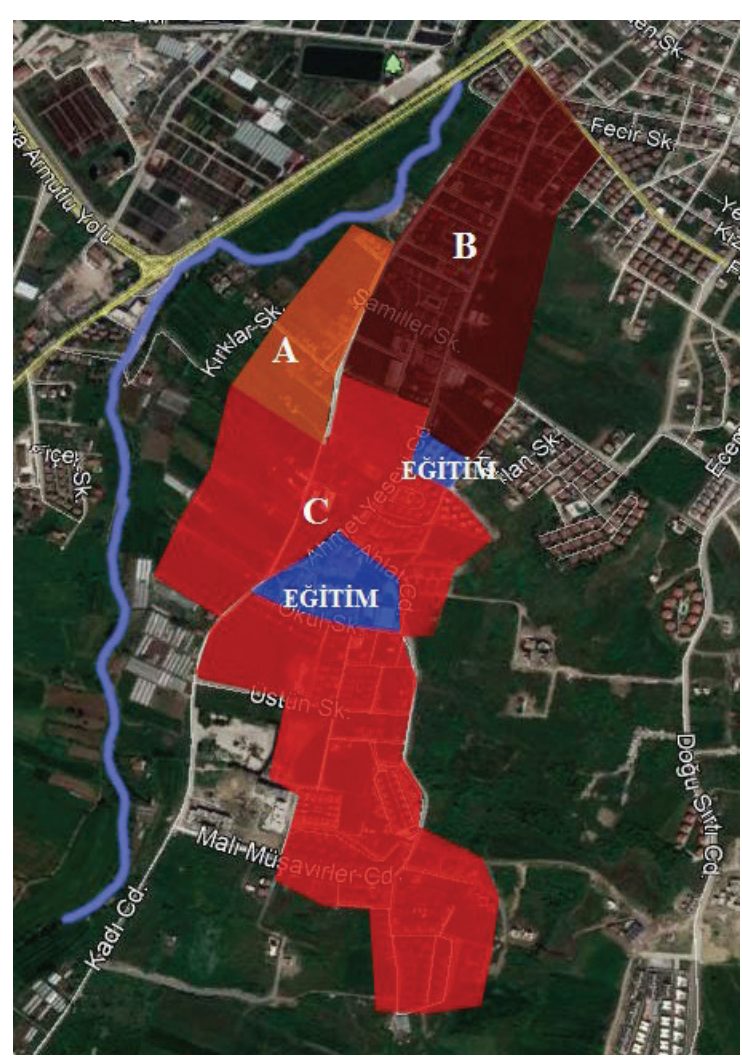

Şekil 4. Arsa değerlerine göre ortaya çıkan bölgeler

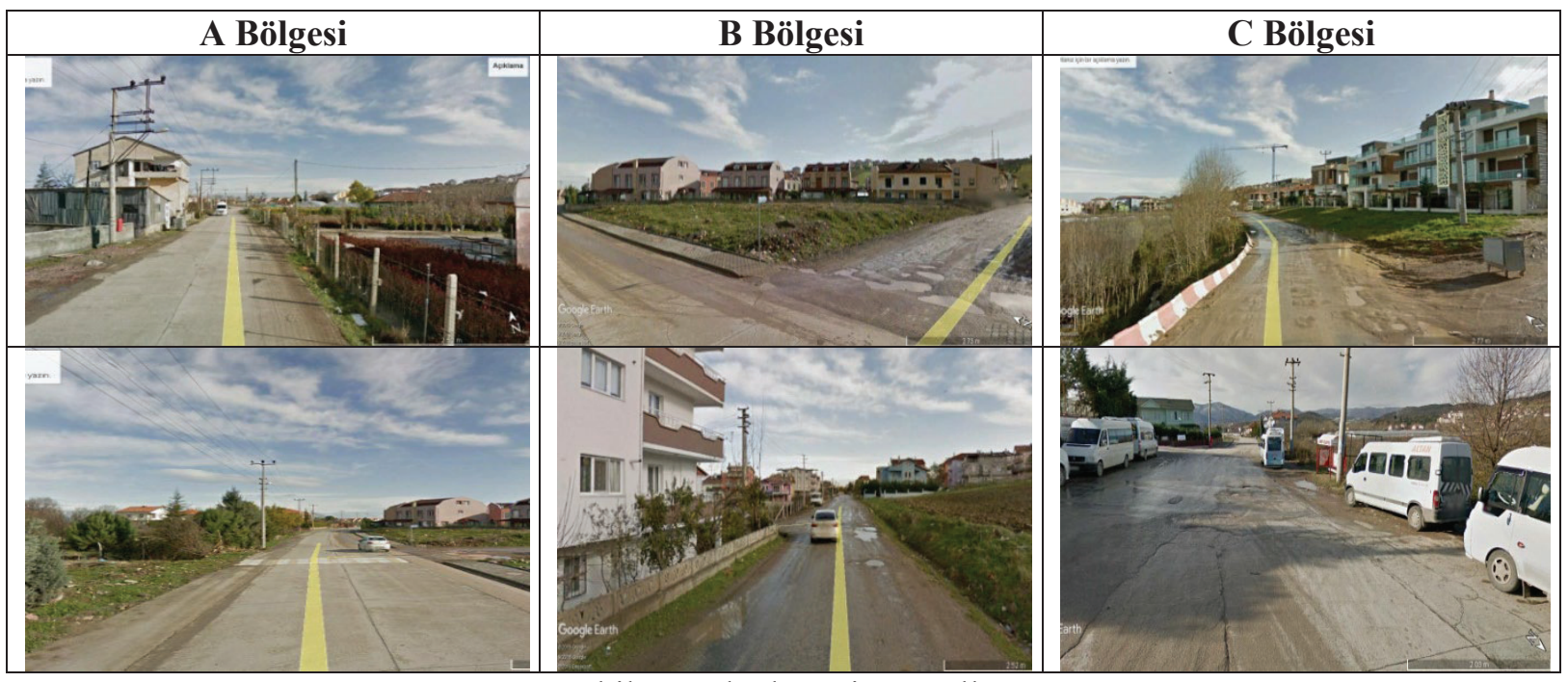

Şekil 5. Bölgelere ait görseller

1998-2010 y1lları arasında arsa $\mathrm{m}^{2}$ değeri en fazla olan bölge sırasıyla $\mathrm{A}>\mathrm{B}>\mathrm{C}$ iken 2010 yılından itibaren $\mathrm{B}>\mathrm{C}>\mathrm{A}$ şeklinde olmuştur. A bölgesinde $\mathrm{m}^{2}$ arsa değeri 1998 y1lında 2 TL iken 2010 yılında $60 \mathrm{TL}, 2014$ 'te $100 \mathrm{TL}$ ve 2018 'de $150 \mathrm{TL}$, B bölgesinde $\mathrm{m}^{2}$ arsa değeri 1998 yılında $2 \mathrm{TL}$ iken 2010 yllında 90 TL, 2014'te 175 TL ve 2018'de 294,29 TL, C bölgesinde ise $\mathrm{m}^{2}$ arsa değeri 1998 yılında 2,5 TL iken 2010 yılında 70 TL, 2014'te 150 TL ve 2018'de 250 TL olmuştur (Şekil 6). 


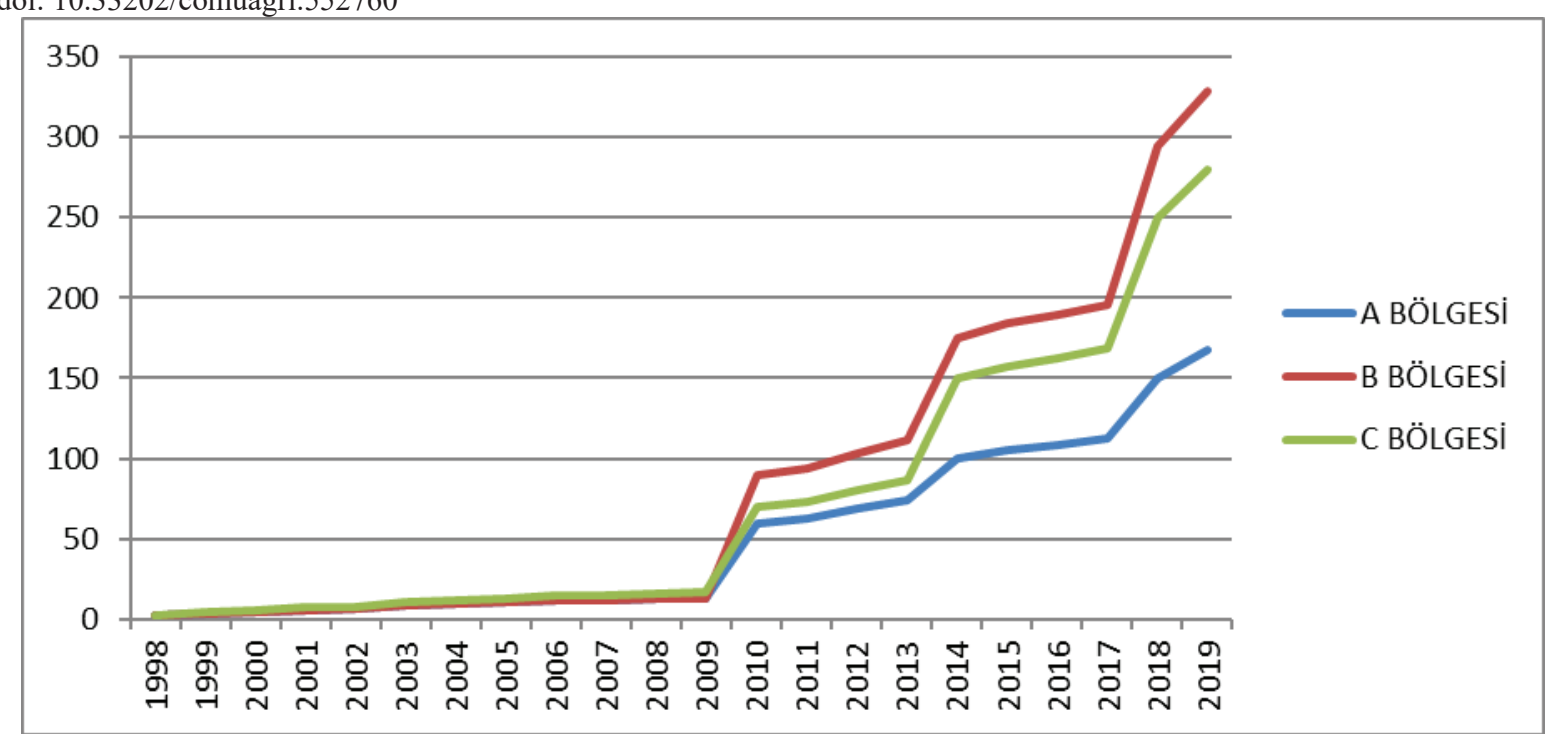

Şekil 6. 1998-2019 yılları arasında arsa değerlerindeki değişim (TL) (Anonim, 2019b)

Çalışma alanı içindeki A bölgesinin diğer bölgelerden daha önce imara açılmış olması sebebiyle başlangıçtaki değeri yüksektir. Ancak zaman içinde A bölgesinin topoğrafik özellikleri ve toprak kalitesi ile sosyo-ekonomik özelliklerine bağl1 olarak değeri düşmüştür (Çizelge 1). Birbirine yakın konumdaki bu bölgelerdeki değer değişimini etkileyen asıl etken imar kararları ve konumları olmuştur. B bölgesinin diğer bölgelere kıyasla Yalova merkeze yakınlığı ve topoğrafik özelliklerine bağlı manzara unsuru değer artışında etkili olmuştur.

Çizelge 1. Arsa değerini etkileyen özelliklerin çalışma alanındaki durumu

\begin{tabular}{|c|c|c|c|}
\hline Özellik* & A Bölgesi & B Bölgesi & C Bölgesi \\
\hline Topoğrafik özellikler & Düz ve düze yakın alandır. & Yükselti değişkendir. & Yükselti değişkendir. \\
\hline Toprak kalitesi & $\begin{array}{l}\text { Bir kısmı, Selimandıra } \\
\text { Deresine daha yakın } \\
\text { olduğundan taşkın } \\
\text { alanında } \\
\text { konumlanmaktadır. Tarım } \\
\text { alanlarına ve alüvyon } \\
\text { toprağa daha yakın } \\
\text { konumdadır. }\end{array}$ & $\begin{array}{l}\text { Tarım alanları ile iç içe } \\
\text { durumdadır. }\end{array}$ & $\begin{array}{l}\text { Tarım alanları ile iç içe } \\
\text { durumdadır. }\end{array}$ \\
\hline Gürültü & $\begin{array}{l}\text { Ulaşıma bağlı kısmen } \\
\text { gürülttü bulunmaktadır. } \\
\text { Genel anlamda şehrin } \\
\text { yoğun gürültüsünden } \\
\text { uzaktır. }\end{array}$ & $\begin{array}{l}\text { Ulaşıma bağlı kısmen } \\
\text { gürülttü bulunmaktadır. } \\
\text { Genel anlamda şehrin } \\
\text { yoğun gürültüsünden } \\
\text { uzaktır. }\end{array}$ & $\begin{array}{l}\text { Okullara ve ulaşıma } \\
\text { bağlı kısmen gürültü } \\
\text { bulunmaktadır. Genel } \\
\text { anlamda şehrin yoğun } \\
\text { gürültüsünden uzaktır. }\end{array}$ \\
\hline Manzara & $\begin{array}{l}\text { Manzara } \\
\text { bulunmamaktadır. }\end{array}$ & $\begin{array}{l}\text { Değişken yükseltisinden } \\
\text { dolayı manzara oluşmakta } \\
\text { ve yüksek kodlardan deniz } \\
\text { görülmektedir. }\end{array}$ & $\begin{array}{l}\text { Değişken yükseltisinden } \\
\text { dolayı manzara } \\
\text { oluşmakta ve yüksek } \\
\text { kodlardan deniz } \\
\text { görülmektedir. }\end{array}$ \\
\hline $\begin{array}{l}\text { Sosyal donatı } \\
\text { alanlarına olan } \\
\text { mesafe } \\
\end{array}$ & $\begin{array}{l}\text { Park ve eğitim alanlarına } \\
\text { yakındır. }\end{array}$ & $\begin{array}{l}\text { Park ve eğitim alanlarına } \\
\text { yakındır. }\end{array}$ & $\begin{array}{l}\text { Park ve eğitim alanlarına } \\
\text { yakındır. }\end{array}$ \\
\hline $\begin{array}{l}\text { Yaşanılan yerin } \\
\text { sosyo-ekonomik } \\
\text { özellikleri }\end{array}$ & $\begin{array}{l}\text { Alt ve orta gelir grubunun } \\
\text { yaşadığı konut alanları } \\
\text { bulunmaktadır. }\end{array}$ & $\begin{array}{l}\text { Orta ve üst gelir grubunun } \\
\text { yaşadığı konut alanları ve } \\
\text { elit yaşam hakimdir. }\end{array}$ & $\begin{array}{l}\text { Orta ve üst gelir } \\
\text { grubunun yaşadığı konut } \\
\text { alanları ve elit yaşam } \\
\text { hakimdir. }\end{array}$ \\
\hline $\begin{array}{l}\text { Şehir merkezine olan } \\
\text { mesafe }\end{array}$ & $\begin{array}{l}\text { Yalova merkeze yaklaşık } \\
2,5 \mathrm{~km} \text { ve Kadıö̈y } \\
\text { merkeze } 3,2 \mathrm{~km} \\
\text { mesafededir. }\end{array}$ & $\begin{array}{l}\text { Yalova merkeze yaklaşık } \\
2,2 \mathrm{~km} \text { ve Kadıköy } \\
\text { merkeze } 3,2 \mathrm{~km} \\
\text { mesafededir. }\end{array}$ & $\begin{array}{l}\text { Yalova merkeze yaklaşık } \\
3,1 \mathrm{~km} \text { ve Kadık̈̈y } \\
\text { merkeze } 2,5 \mathrm{~km} \\
\text { mesafededir. }\end{array}$ \\
\hline
\end{tabular}


doi: 10.33202/comuagri.552760

\begin{tabular}{|c|c|c|c|}
\hline $\begin{array}{l}\text { Farklı ulaşım } \\
\text { türlerine olan mesafe }\end{array}$ & $\begin{array}{l}\text { Taşıt yollarına ve toplu } \\
\text { taşımaya yakındır. }\end{array}$ & $\begin{array}{l}\text { Taşıt yollarına ve toplu } \\
\text { taşımaya yakındır. }\end{array}$ & $\begin{array}{l}\text { Taşıt yollarına ve toplu } \\
\text { taşımaya yakındır. }\end{array}$ \\
\hline \multirow[t]{2}{*}{$\begin{array}{l}\text { İmar durumu ve } \\
\text { Taks/Kaks değerleri }\end{array}$} & $\begin{array}{l}2010 \text { yılı imar planına } \\
\text { göre; } \\
\text { A-2 } \\
\text { Taks: } 0.30 \\
\text { Kaks: } 0.60 \\
\text { Taşkın sahası içinde ve } \\
\text { çeperinde. }\end{array}$ & $\begin{array}{l}2010 \text { yılı imar planına } \\
\text { göre; } \\
\text { A-2 } \\
\text { Taks: } 0.30 \\
\text { Kaks: } 0.60\end{array}$ & $\begin{array}{l}2010 \text { yılı imar planına } \\
\text { göre; } \\
\text { A-2 } \\
\text { Taks: } 0.20 \\
\text { Kaks: } 0.40 \\
\text { Bir kısmı tarım alanı. }\end{array}$ \\
\hline & $\begin{array}{l}2018 \text { yılı imar planına } \\
\text { göre; } \\
\text { A-2 } \\
\text { Taks: } 0.30 \\
\text { Kaks: } 0.60 \\
\text { Taşkın sahası içinde ve } \\
\text { çeperinde. }\end{array}$ & $\begin{array}{l}2018 \text { yılı imar planına } \\
\text { göre; } \\
\text { A-2 } \\
\text { Taks: } 0.30 \\
\text { Kaks: } 0.60\end{array}$ & $\begin{array}{l}2018 \text { yılı imar planına } \\
\text { göre; } \\
\text { A-2 } \\
\text { Taks: } 0.30 \\
\text { Kaks: } 0.60 \\
\text { Bir kısmı tarım alanı. }\end{array}$ \\
\hline
\end{tabular}

Çalışma alanı, 2018 yılı 1/50.000 ölçekli Yalova Çevre Düzeni Planında da gelişme konut alanı olarak gösterilmiş ve Kadıköy için eğitim kenti kimliği belirlenmiştir. Çalışma yapılan alanın okullar bölgesinde olması Kadıköy için belirlenen bu misyonu destekler nitelikte olup, daha çok orta ve üst gelir grubunun tercih etmesiyle cazibesinin daha da artacağı açıktır. Aynı zamanda bu bölgede verimli tarım toprakları bulunmasına rağmen zaman içinde getirisi daha yüksek olan imarlı arsaya dönüşümü tercih edilmektedir.

Çalışma alanındaki 2010, 2014 ve 2018 yıllarında ani fiyat artışları bu yıllarda yapılan imar planı çalışmalarına bağlanabilmektedir. Yapılmış olan imar planlarında çalışma alanındaki bölgeler büyük oranda gelişme konut alanı şeklinde gösterilmiş ve yapılaşma koşulları belirlenmiştir. Farklı yıllara ait planlar karşılaştırıldığında; 2010 yılına ait planda A ve B bölgesinin Taks/ Kaks değerinin 0,30/0,60 ve C bölgesindeki değerin 0,20/0,40 iken 2018 yılında üç bölgede de Taks/ Kaks değerinin 0,30/0,60 olduğu görülmektedir (Şekil 7). Yapılan planlama çalışmalarında 2014 yılı itibari ile Gemlik-Armutlu-Çınarcık-Yalova çevre yolu yer almaya başlamıştır (Şekil 8). Çevre yolunun çalışma alanı sınırları içinden geçmesi bu bölgedeki canlılığı artıracağı düşüncesine sebep olarak 2014 yılındaki emlak değerlerini etkilemiştir. Ayrıca, 2018 yılında yaşanan enflasyon oranındaki yükseliş da değer artışı üzerinde etkili olmuştur.

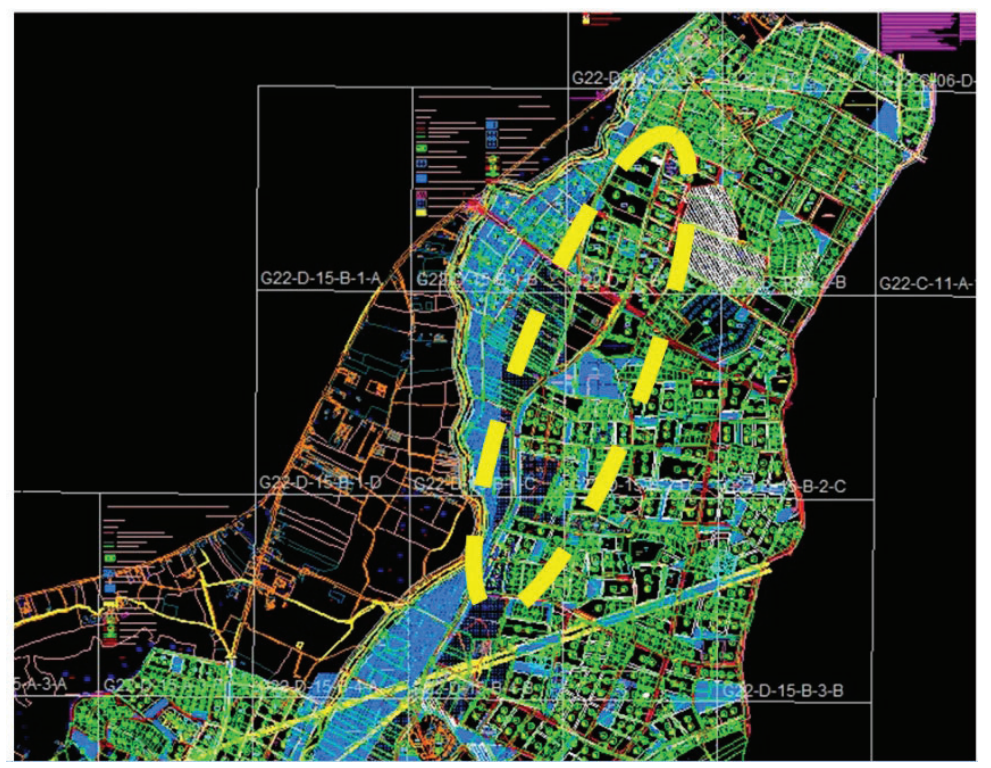

Şekil 7. Kadıköy Belediyesi ilave- revizyon imar planı (2010 yılı) 


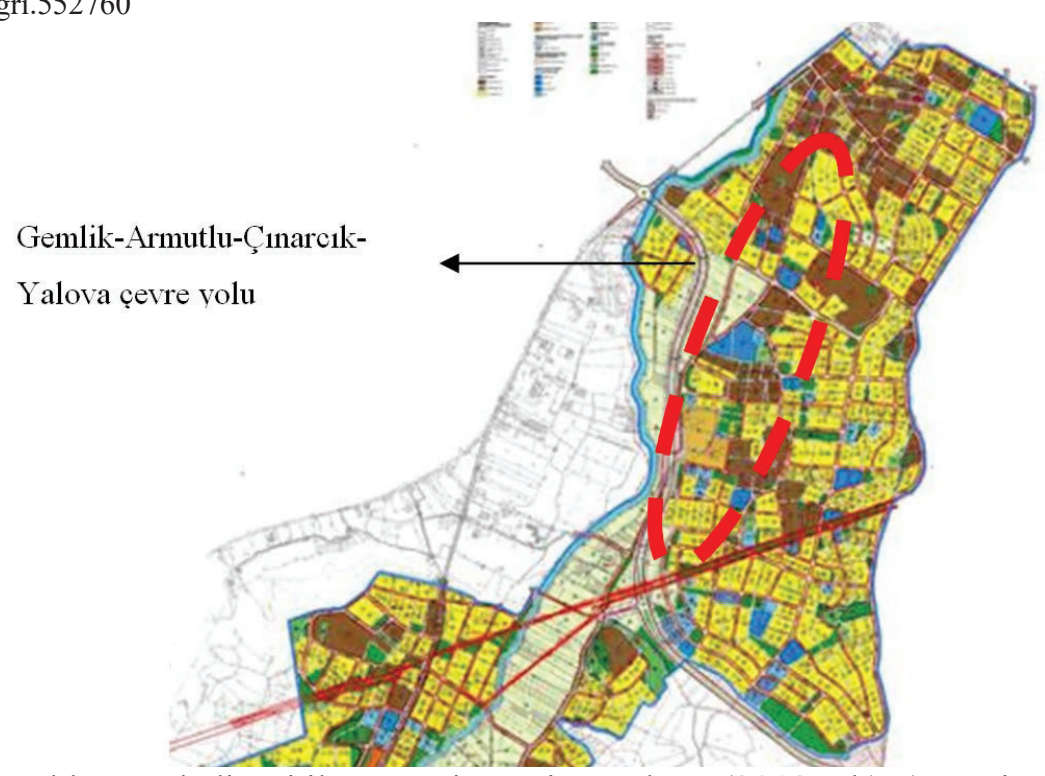

Şekil 8. Kadıköy Belediyesi ilave- revizyon imar planı (2018 yıl1) (Anonim, 2019c)

Çalışma yapılan bölgede, çeşitli etmenlere bağlı olarak arsa değerlerinde değişim yaşanmakta ve tarım topraklarının arsaya dönüşümü giderek artmaktadır.

\section{Sonuç}

Merkeze yakınlık ve yeşil dokusu nedeniyle nüfusun bu bölgeyi yaşam alanı olarak tercih etmesi giderek betonlaşmayı artırmaktadır. Alanda yapılan gözlemlerin ve uydu görüntülerinin değerlendirilmesine göre çalışma alanında;

Mülk sahipliğinde değişim

Tarım ve hayvancılıkta azalma (sektörel değişim)

Toplumsal değişim (farklı kültürlere sahip, gelir düzeyi orta ve üst olan kişiler bölgede yer seçmekte)

Ulaşım aksında yoğunluk (minibüs hattı, servis araçları)

Yapılaşma yoğunluğunda artış, yaşanmaktadır.

Tarım alanlarının amaç dışı kullanımının önlenmesi ya da sınırlanması amacıyla yasal mevzuatın yeniden düzenlenmesi gereklidir. Alana ait planlarda yapılan değişiklikler, planlama çalışmalarının arsa değeri üzerinde önemli bir paya sahip olduğunu göstermiştir. Çalışma alanı içinde yerleşmenin yayılmaya başladığı A bölgesi zamanla cazibesini yitirmiş, bunun yerine B bölgesi öne çıkmıştır. Genel anlamda şehrin yoğun gürültüsünden uzak olması, değişken yükseltisinden dolayı manzaranın ve özellikle daha yüksek kotlarda deniz manzarasının bulunması, park ve eğitim alanlarına yakınlığı, Yalova merkeze yakın konumda olması, genellikle orta ve üst gelir grubuna sahip kişilerin tercih etmesi B bölgesi ve beraberinde C bölgesinin değerini artırmıştır. Taşkın sahasında yer alan, daha düşük kotta bulunan ve manzarası bulunmayan A bölgesi ise eski çekiciliğini ve arsa değerini zamanla kaybetmiştir. Alanın doğal özelliklerinin yanı sıra eğitim, sağlık, ticaret, sosyo-kültürel tesis gibi sosyal donatı alanlarına yakınlığı çekiciliğini artırarak arsa değerini etkilemektedir. Dolayısıyla, kontrollü büyüme ve sürdürülebilirlik açısından doğru planlama kararları önem taşımaktadır. Sonuç olarak, bütüncül planlama anlayışı çerçevesinde koruma-kullanma dengesini sağlayan uygulamalar yapılmalıdır. İmar planlarında tarım alanlarında baskıya yol açmadan uygun yerlerde yeni fonksiyon alanları ve yeterli büyüklükte sosyal donatı alanlarına yer verilmelidir. 


\section{Kaynaklar}

Akci, A., Demirel, M.K., Becu, H.Ş., 2016. Tarım arazilerindeki yapılaşma baskısının azaltılmasında köy gelişme alanı ve imar uygulamaları: İç Anadolu bölgesi örneği. Nevşehir Bilim ve Teknoloji Dergisi TARGID. Özel Say1: 372-384.

Anonim, 2019a. Emlak Dehas1, www.emlakdehasi.com/gayrimenkul-yatirim-rehber/emlak-yatirim/arazinin degerini-etkileyen-15-ozellik/. (Erişim tarihi:12.01.2019).

Anonim, 2019b. Kadıköy Belediyesi, www.kadikoy.bel.tr. (Erișim tarihi:12.01.2019).

Anonim, 2019c. And Planlama, www.andplanlama.com.tr/p-220-yalova-ili-kadikoy-beldesi-ila.html, (Erişim tarihi:31.03.2019).

Dernek, Z. 2006. Cumhuriyet'in kuruluşundan günümüze tarımsal gelişmeler. Süleyman Demirel Üniversitesi Ziraat Fakültesi Dergisi. 1(1):1-12.

Fan, J., Wang, Y., Zhou, Z., You, N., Meng, J. 2016. Dynamic ecological risk assessment and management of land use in the middle reaches of the heihe river based on landscape patterns and spatial statistics. Sustainability. 8(6): 536.

Kılıç, M., 2008. Tarım arazilerinin amaç dıșı kullanımının hukuki ve sosyo-ekonomik boyutları: Çorum ili merkez ilçesi toprak sanayi işletmeleri örneği. Ankara Üniversitesi Fen Bilimleri Enstitüsü, Doktora Tezi.267 s.

Nas, İ., 2016. Kentleşmenin tarım alanlarına etkisinin yasal ve yönetsel açıdan irdelenmesi: Denizli örneği. Bartın Üniversitesi Fen Bilimleri Enstitüsü, Yüksek Lisans Tezi. 117 s.

Ökmen, M., Yurtsever, H., 2010. Kentsel planlama sürecinde oluşan kamusal rantın vergilendirilmesi. Maliye Dergisi. 158: 58-74.

Özbek, A.K., Öztaş, T., 2004. Tarım arazilerinin amaç dışı kullanımı: Erzurum örneği. Ekoloji Dergisi. 52: 1-6.

Rees, W., Wackernagel, M., 2008. Urban Ecological Footprints: Why Cities Cannot Be Sustainable and Why They Are a Key to Sustainability. In Urban Ecology, Springer, pp. 537-555. Boston, MA.

Sezgin, D., Varol, Ç., 2012. Ankara'daki kentsel büyüme ve saçaklanmanın verimli tarım topraklarının amaç dışı kullanımına etkisi. METU JFA. 29(1): 273-288.

Topçu, P., 2012. Tarım Arazilerinin Korunması ve Etkin Kullanılmasına Yönelik Politikalar, Uzmanlık Tezi, Kalkınma Bakanlığı İktisadi Sektörler ve Koordinasyon Genel Müdürlüğü Yayınları. 145 s. Ankara.

Yenigül, S.B. 2016. Büyükşehirlerde tarımsal alanların korunmasında kentsel tarım ve yerel yönetimlerin rolü. MEGARON. 11(2): 291-299.

Yomralığlu, T., 1992. Arsa ve arazi düzenlemesi için yeni bir uygulama şekli. Harita ve Kadastro Mühendisleri Odası Yayın Organı. No.73. s.30-43. Ankara. 